\title{
Travelling through a warming world: climate change and migratory species
}

\author{
Robert A. Robinson ${ }^{1, *}$, Humphrey Q. P. Crick $^{1}$, Jennifer A. Learmonth ${ }^{2}$, \\ Ilya M. D. Maclean ${ }^{1}$, Chris D. Thomas ${ }^{3}$, Franz Bairlein ${ }^{4}$, Mads C. Forchhammer ${ }^{5}$, \\ Charles M. Francis ${ }^{6}$, Jennifer A. Gill ${ }^{7}$, Brendan J. Godley ${ }^{8}$, John Harwood ${ }^{9}$, \\ Graeme C. Hays ${ }^{10}$, Brian Huntley ${ }^{11}$, Anthony M. Hutson ${ }^{12}$, Graham J. Pierce ${ }^{2}$, \\ Mark M. Rehfisch ${ }^{1}$, David W. Sims ${ }^{13,14}$, M. Begoña Santos ${ }^{2}$, Timothy H. Sparks ${ }^{15}$, \\ David A. Stroud ${ }^{16}$, Marcel E. Visser ${ }^{17}$ \\ ${ }^{1}$ British Trust for Ornithology, The Nunnery, Thetford, Norfolk IP24 2PU, UK \\ ${ }^{2}$ Dept Zoology, University of Aberdeen, Tillydrone Ave, Aberdeen AB24 2TZ, UK \\ ${ }^{3}$ Dept Biology, University of York, PO Box 373, York YO10 5YW, UK \\ ${ }^{4}$ Institute of Avian Research, 'Vogelwarte Helgoland', An der Vogelwarte 21, 26386 Wilhelmshaven, Germany \\ ${ }^{5}$ Dept. of Arctic Environment, National Environmental Research Institute, Frederiksborgvej 399, PO Box 358, 4000 Roskilde, Denmark \\ ${ }^{6}$ Canadian Wildlife Service, Environment Canada, Ottawa, Ontario K1A 0H3, Canada \\ ${ }^{7}$ Centre for Ecology, Evolution \& Conservation, University of East Anglia, Norwich NR4 7TJ, UK \\ ${ }^{8}$ Centre for Ecology \& Conservation, School of Biosciences, University of Exeter, Cornwall Campus TR10 9EZ, UK \\ ${ }^{9}$ Centre for Research into Ecological and Environmental Modelling, The Observatory, University of St. Andrews, \\ St Andrews, Fife KY16 9LZ, UK \\ ${ }^{10}$ Institute of Environmental Sustainability, Swansea University, Singleton Park, Swansea SA2 8PP, UK \\ ${ }^{11}$ Institute of Ecosystem Science, School of Biological and Biomedical Sciences, University of Durham, Durham DH1 3LE, UK \\ ${ }^{12}$ Winkfield, Station Road, Plumpton Green, East Sussex BN7 3BU, UK \\ ${ }^{13}$ Marine Biological Association of the UK, The Laboratory, Citadel Hill, Plymouth PL1 2PB, UK \\ ${ }^{14}$ Marine Biology and Ecology Research Centre, School of Biological Sciences, University of Plymouth, Drake Circus, \\ Plymouth PL4 8AA, UK \\ ${ }^{15}$ Centre for Ecology and Hydrology, Huntingdon, Cambridgeshire PE28 2LS, UK \\ ${ }^{16}$ Joint Nature Conservation Committee, Monkstone House, Peterborough PE1 1JY, UK \\ ${ }^{17}$ Netherlands Institute of Ecology (NIOO-KNAW), 6666 ZG Heteren, The Netherlands
}

\begin{abstract}
Long-distance migrations are among the wonders of the natural world, but this multitaxon review shows that the characteristics of species that undertake such movements appear to make them particularly vulnerable to detrimental impacts of climate change. Migrants are key components of biological systems in high latitude regions, where the speed and magnitude of climate change impacts are greatest. They also rely on highly productive seasonal habitats, including wetlands and ocean upwellings that, with climate change, may become less food-rich and predictable in space and time. While migrants are adapted to adjust their behaviour with annual changes in the weather, the decoupling of climatic variables between geographically separate breeding and nonbreeding grounds is beginning to result in mistimed migration. Furthermore, human land-use and activity patterns will constrain the ability of many species to modify their migratory routes and may increase the stress induced by climate change. Adapting conservation strategies for migrants in the light of climate change will require substantial shifts in site designation policies, flexibility of management strategies and the integration of forward planning for both people and wildlife. While adaptation to changes may be feasible for some terrestrial systems, wildlife in the marine ecosystem may be more dependent on the degree of climate change mitigation that is achievable.
\end{abstract}

KEY WORDS: Birds · Marine mammals · Turtles · Fish • Phenology • Population change • Conservation 


\section{INTRODUCTION}

Climate change is one of the most significant threats to global ecosystems and biodiversity (King 2004, Thomas et al. 2004, MEA 2005). The increase in global temperature between 1900 and 2000 was the largest for any century during the past 1000 years (Huntley et al. 2006, Osborn \& Briffa 2006, IPCC 2007); even if greenhouse and other gaseous emissions do not increase further, this warming is expected to continue (Meehl et al. 2005). There is compelling evidence that animals and plants have been affected by recent global changes in temperature (Walther et al. 2002, Parmesan \& Yohe 2003, Root et al. 2003), potentially leading to extinction of species in a wide range of taxa (Thomas et al. 2004), although this has so far only been documented amongst amphibians (Pounds et al. 2006). Much research has focussed on the impacts of increased temperatures (and the consequences thereof, such as reduced snow/ice extent and increases in sealevel); however, other climate variables, such as precipitation and the frequency of extreme events are also changing, though the magnitude of these changes differs markedly between regions (IPCC 2007), so impacts are harder to predict.

Migratory species represent something of a paradox in the assessment of risk posed by climate change to biodiversity. Because they are mobile, and populations frequently exhibit multiple migratory strategies, they might be expected to track changes in the locations of suitable environments across the globe. On the other hand, they are dependent upon the availability of suitable habitat in multiple locations (in breeding, migration, and non-breeding areas), all of which may be affected by climate change in different ways, greatly increasing the potential for deleterious impacts at some point in the annual cycle. Typically, movements are between breeding areas (where resources are plentiful and where most reproduction occurs) and non-breeding areas, to which individuals move when conditions on the breeding grounds become inclement, or resource availability is reduced. Because they move between widely dispersed areas, migration can occupy a major part of the life cycle, and account for significant mortality (Sillett \& Holmes 2002, Newton 2007).

This review stems from information prepared for the Convention on the Conservation of Migratory Species of Wild Animals (CMS; Anonymous 2003) prior to it adopting a Resolution recognising the importance of climate change, and calling on signatory parties to implement adaptation measures in the conservation of relevant species (UNEP/CMS/CoP/Res8.13). In addition to carrying out a review of the literature, a group of experts was assembled to identify the major risks from climate change for each major taxonomic group (Table 1). We concentrate largely on migratory vertebrates as these are the focus of the CMS, and they are

Table 1. Summary of likely climate change impacts on population dynamics of migratory species. Approximate number of migratory species in each group (as a percentage of all species) is listed. Knowledge of each group is ranked: ${ }^{* * *}$ good for at least some species, ${ }^{* *}$ moderate for at least some species, or * little or no knowledge. For each climate change we indicate qualitatively whether species in the group are likely to be significantly affected; particularly important effects that are (relatively) well documented are noted; ?: areas of particular uncertainty. -: factors not generally relevant for a group. These rankings were arrived at following a 2 d discussion workshop (held in Cambridge, March 2005) involving the authors and a number of other experts (listed in the 'Acknowledgements') and represents the consensus of those discussions

\begin{tabular}{|c|c|c|c|c|c|c|c|}
\hline & Birds & Bats & $\begin{array}{l}\text { Terrestrial } \\
\text { mammals }\end{array}$ & $\begin{array}{l}\text { Marine } \\
\text { mammals }\end{array}$ & $\begin{array}{l}\text { Sea } \\
\text { turtles }\end{array}$ & Fish & Insects \\
\hline $\begin{array}{l}\text { Number of } \\
\text { migratory species }\end{array}$ & $1530(16 \%)$ & $113(10 \%)$ & 30 (са. $1 \%$ ) & $43(36 \%)$ & $7(100 \%)$ & $874(3 \%)$ & $?$ \\
\hline Knowledge & $* * *$ & $* *$ & $* *$ & $* *$ & $* *$ & * & * \\
\hline Increased temperatures & Yes & Yes & No? & Yes & Yes & Important & Yes \\
\hline Changed precipitation & Yes & $?$ & Yes & No & Yes & No & $?$ \\
\hline $\begin{array}{l}\text { Loss of breeding } \\
\text { habitat }\end{array}$ & Yes & Yes & Yes & Important & Important & Yes? & Yes \\
\hline $\begin{array}{l}\text { Loss of non-breeding } \\
\text { habitat }\end{array}$ & $\begin{array}{l}\text { Yes (important } \\
\text { for some) }\end{array}$ & $\begin{array}{l}\text { Yes (important } \\
\text { for some) }\end{array}$ & Yes & Yes & No? & - & Yes \\
\hline Loss of migration & $\begin{array}{l}\text { Yes (important } \\
\text { for some) }\end{array}$ & Yes & Yes & No? & No? & Yes? & Yes? \\
\hline Loss of stopover sites & $\begin{array}{l}\text { Important for } \\
\text { some species }\end{array}$ & $?$ & - & - & - & - & - \\
\hline Longer migratory pathways & Yes & $?$ & Yes? & Yes & No? & $?$ & $?$ \\
\hline Changes in food availability & Yes & Yes & Mostly no & Important & $?$ & Yes & Mostly no \\
\hline Mismatch in timing & Important? & $?$ & $?$ & $?$ & - & Yes & Sometimes \\
\hline Inter-species competition & $?$ & $?$ & Yes & No? & No & No? & No? \\
\hline
\end{tabular}


Box 1. Migration

Migration is a behavioural adaptation to seasonal environments; individuals can successfully exploit temporarily abundant resources, but can escape harsh physical conditions prevalent at other times. In contrast, sedentary species tend to inhabit regions of more continuous resource availability where the physical conditions are more benign, or hibernate to escape periods of resource scarcity.

Migration has evolved many times, and consequently there are many definitions of precisely what constitutes a migratory taxon (Dingle 1996). For most vertebrates, the focus is on predictable return journeys of individuals. This is less appropriate when considering invertebrate (particularly insect) taxa, in which the migratory cycle may be completed over a number of generations. The Convention on the Conservation of Migratory Species of Wild Animals (CMS, Anonymous 2003), the primary international legal instrument for conserving migratory species (at least outside the New World), defines them as 'those in which a significant proportion of whose members cyclically and predictably cross one or more national jurisdictional boundaries'. This is a political, rather than biological definition, and again favours vertebrates; only one invertebrate, the monarch butterfly, is listed. Migratory journeys may involve individuals (1) moving in relatively small stages, exploiting habitat more or less continuously during the journey, e.g. many bats or marine mammals, or (2) travelling directly between a relatively small number of widely separated, more or less discrete, sites, e.g. wader (Charadrii) species.

Swimming and, especially, flying vertebrates have the capacity for long-distance migration, but for others the cost of locomotion is generally too great. This results in a very uneven taxonomic distribution of migratory species
(Table 1). Migratory birds can nest in the high Arctic (or Antarctic) and winter at much lower latitudes; some fish migrate from tropical seas to temperate zone rivers, and some marine mammals migrate from the equator to the polar oceans, whereas terrestrial mammals, for example, tend to migrate limited distances along elevation or moisture gradients.

Knowledge of migratory movements, and hence of the potential impacts of climate change, varies markedly between taxa. Although 113 bat species are thought to be migratory, there is sufficient information to determine threats in only $25(22 \%)$; similarly there is little, or no, information on the migratory status of about a third of small cetaceans (Riede 2001). Relatively few terrestrial mammals are migratory; most are large herbivores that follow seasonal vegetation growth (Berger 2004). The number of bird species that migrate varies with latitude; most species at higher latitudes are either migratory or undertake longrange seasonal movements (Berthold 2001). Baleen whales undertake long, seasonal migrations between tropical calving grounds in winter and high latitude feeding grounds in summer, while movements of odontocetes are more variable, with both north-south and inshore-offshore seasonal movements observed. All marine turtles undertake longrange movements (Hays 2008), as do many species of marine fish; however, the nature of migratory journeys in marine taxa is generally poorly understood (Learmonth et al. 2006). Very little is known about the migratory behaviour of invertebrates; most attention has focussed on pest species, or the charismatic Lepidoptera, although most groups, particularly larger insects, cephalopod molluscs and marine crustacea, have representatives that can be considered migratory. the species that primarily undertake long-distance migratory journeys (Box 1) and for which most research exists; we do, however, consider some invertebrate groups, such as butterflies (Insecta: Lepidoptera) and squid (Cephalopoda: Teuthida), where information is available. First, we assess the risks and opportunities from climate change faced by migrant species because they (1) occur in specific types of habitat, (2) undertake often hazardous migrations, and (3) must time their arrival at breeding and non-breeding grounds in relation to resource availability there. We then go on to address the key knowledge gaps and the types of measures required for conserving migratory species, which include some of the most iconic species of the earth's fauna (e.g. Fig. 1).

\section{IMPACTS OF CLIMATE CHANGE}

\section{Habitat associations}

Migration is a strategy to exploit seasonal environments, so migratory species occur disproportionately at higher latitudes and in habitats that exhibit marked seasonality in resource availability, such as many wetland areas. In the short term, increasing temperatures are likely to lead to increased resource availability in northern polar regions and hence increased populations (Jensen et al. 2008), but, in the longer term, it is thought likely that many species will experience significant resource or habitat loss (Zöckler \& Lysenko 2000, Meltofte et al. 2007).

The effects of global warming are expected to be especially severe in wetlands because increased water demands for domestic, industrial and agricultural use with rising temperatures and human populations will all lower water tables (Sala et al. 2000, MEA 2005). Coastal habitats have long suffered from human use (Lotze et al. 2006), and existing habitat will be further threatened as it is increasingly squeezed between rising waters and the land, especially where it is protected by 'hard' man-made defences (Atkinson et al. 2004). Replacement habitat is unlikely to be extensive (and may take many years to develop), as low-lying areas often provide the most fertile agricultural land and are home to millions of people. This will mean, for example, a loss of egg-laying beaches for sea turtles (Fish et al. 2005), loss of feeding habitat for coastal 


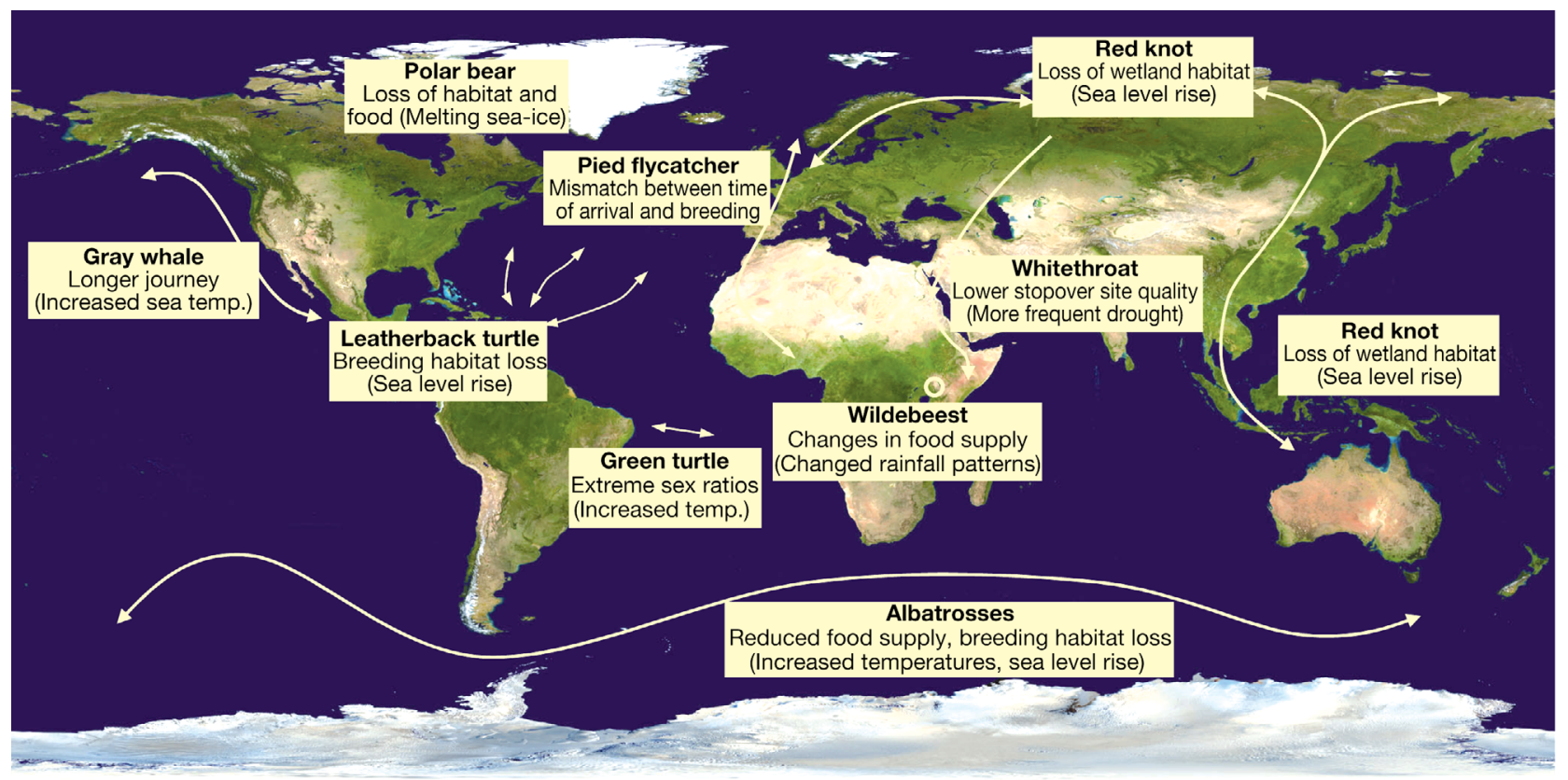

Fig. 1. Impacts of climate change on migratory animals; examples indicate the geographical and taxonomic range of animals affected and some of the key impacts. Albatrosses Diomedea spp., Weimerskirch et al. (2003); gray whale Eschrichtius robustus, Moore et al. (2003); green turtle Chelonia mydas, Godley et al. (2002); leatherback turtle Dermochelys coriacea, Fish et al. (2005); pied flycatcher Ficedula hypoleuca, Both et al. (2006); polar bear Ursus maritimus, Derocher et al. (2004); red knot Calidris canutus, Piersma \& Lindström (2004); whitethroat Sylvia communis, Winstanley et al. (1974); wildebeest Connochaetes taurinus, Fryxell \& Sinclair (1988); background image @NASA (visibleearth.nasa.gov)

waterbirds (Rehfisch et al. 2004) and of, already scarce, haul-out sites that seals use for breeding, nurseries and resting (Baker et al. 2006). In the Arctic and Antarctic, the predicted substantial contraction in sea-ice cover will reduce the breeding and feeding habitat of species such as seals and polar bears Ursus arctos in the Arctic (Barber \& Iacozza 2004) and seabirds in the Antarctic (Croxall et al. 2002).

Unlike vertebrates, which have the capacity to cross hundreds or thousands of kilometres, yet still home in on specific breeding, stop-over or non-breeding sites, most insect species have much more diffuse migratory patterns, and are heavily dependent on appropriate weather conditions. In addition, return migrants are normally not the same individuals (or even of the same generation) that migrated originally and, with the notable exception of winter roost sites of the monarch butterfly Danaus plexippus, they do not seek specific sites. Consequently, migration is only likely to be a successful strategy for insects that are associated with widespread, albeit still seasonal, habitats, and such species are doing well (Warren et al. 2001), as migratory journeys may be becoming easier.

In marine ecosystems, phytoplankton abundance is strongly related to temperature, and large-scale shifts in distribution in response to temperature changes have been observed (Hays et al. 2005). Being at the base of many marine food webs, changes in phytoplankton biomass have affected zooplankton abundance and, consequently, the demography of migratory fish (Perry et al. 2005), squid (Waluda et al. 2001), and other predators further up the food chain, such as pinnipeds (Forcada et al. 2005) and cetaceans (Keiper et al. 2005). Many marine species forage in areas of nutrient-rich oceanic upwelling, which may change in strength, shift location or become less predictable (Harwood 2001). Of growing concern is an increase in the dissolved $\mathrm{CO}_{2}$ content in oceanic waters, and the resulting decrease in $\mathrm{pH}$, which will have profound effects on metabolic processes (Pörtner et al. 2004). The long-term consequences of this for the capacity of individuals to migrate, and for the abundance of key prey species, are unknown, but such profound changes are unlikely to be easily reversible.

Migratory species can be common, or even dominant, members of biological assemblages, so changes in their numbers, routes or timing of migration may have wide-ranging environmental, economic or social consequences. For example, African grasslands are sensitive to seasonal variation in grazing pressure. Alterations in the migratory routes of large mammalian herbivores in response to changed rainfall patterns affect productivity and vegetation succession in the ecosystem, with potential consequences for other graz- 
ers and predators (Fryxell \& Sinclair 1988), and may result in increased conflicts with humans (Thirgood et al. 2004). Migratory species can also be important in aiding the dispersal of (alien) plants and invertebrates (Green \& Figuerola 2005), or in spreading zoonotic diseases, such as chytridiomycosis (Pounds et al. 2006), or avian influenza (Olsen et al. 2006; though not, apparently, the recently evolved H5N1 strain, Gauthier-Clerc et al. 2007).

\section{Hazardous journeys}

Moving long distances exposes migrants to additional risks from climate change, but their ability to move long distances also provides potential for their salvation. For example, breeding dispersal (movement of adults between breeding sites each year) is on average greater for migrant than resident birds and, among migrant species, those with greater dispersal displayed more positive recent population trends during 19691994 (Paradis et al. 1998). Similarly, amongst insects (Warren et al. 2001) and seabirds (Oedekoven et al. 2001), those species with greater dispersal are better able to respond adaptively to warming temperatures.

Although genetic or cultural constraints can limit the ability of a species to alter migratory journeys (Sutherland 1998), modifications as a result of climate change have been well documented among birds (Fiedler 2003). For example, as a response to warmer temperatures, some European shorebirds are wintering further north and east than traditionally, closer to their breeding grounds (Austin \& Rehfisch 2005). Baleen whales, on the other hand, which migrate between tropical and polar waters, are facing longer journeys and reduced feeding opportunities as suitable bioclimatic zones creep poleward (Learmonth et al. 2006). Longer journeys are also predicted for at least some transequatorial migrant birds between Africa and Europe (Huntley et al. 2006).

Birds, insects and many marine species ride winds or currents to aid their migratory journeys, making some of the longest distance migrations possible (Wirth \& Bernatchez 2003, Deveson et al. 2005). Alteration of these currents or winds might make journeys easier, but is more likely to increase energy demands and/or deliver individuals to the wrong locations or at the wrong time (Liechti 2006). In marine ecosystems, the presence of thermal front boundaries and stratified water constrains migratory routes; increasing sea temperatures will alter the location, strength and persistence of these fronts, potentially changing migratory routes and timings and hence population structure (Hunter et al. 2004, Sims et al. 2006). Furthermore, shifts in human fishing activity as a result of climate fluctuation effects on the location of non-migratory resources may result in spatially constrained fisheries, where higher capture rates of migratory animals, such as fish, are more likely (Southall et al. 2006). Similarly, in non-marine systems changes in migratory routes may be constrained by unsuitable habitat or man-made barriers, such as fences, which may impede herbivore migrations (Boone \& Hobbs 2004), or dams, which limit seasonal movements of river dolphins (Harwood 2001) and may constrain the ability of fish migrating up warmer rivers to find suitable, cool, headwaters. Of course, the frequency of dams (to store increasingly scarce water resources or to generate hydropower) and fences (to protect profitable agricultural areas) may also increase in response to climate changes. A major effect of climate change will be increased drying at mid to low latitudes adjacent to existing deserts (IPCC 2007). These areas already pose significant barriers to land migrants and increases in their extent can only make migratory journeys more hazardous.

In addition to suitable habitat at either end of their journey, many migratory species require an ecologically coherent habitat network that they can use en route. The degree of connectivity between areas will vary between species and will have important implications for the potential of populations to adapt to changing conditions (Webster et al. 2002). Changes in any area used by a migratory species are likely to affect all populations of a species, even those that do not use them directly, because of density-dependent habitat selection and mortality (Sutherland 1996, Newton 2006). The quality of these habitats is particularly important for migrants that use a limited number of widely separated, and often highly productive, stopover sites. Species that need to cross an ecological barrier, such as desert, mountains or ocean, require a large amount of high quality food in a short period of time to ensure they are able to cross the barrier and arrive in good physical condition (Berthold 2001, Bairlein \& Hüppop 2004). Failure to arrive in good condition may result in reduced survival or fecundity at later stages in the life-cycle (e.g. Gill et al. 2001, Baker et al. 2004, Norris et al. 2004), which may be exacerbated by positive feedback mechanisms, with individuals using the best non-breeding areas able to return to the best breeding sites, because they migrate earlier or faster (Gunnarsson et al. 2005). Climatic impacts on migration are likely to be most important for the prebreeding migration because timing of arrival in the breeding areas is critical (Kokko 1999). Moreover, any additional mortality, or loss of condition, will have a direct effect on breeding population size, unlike mortality on post-breeding migration, which may be compensated for by density-dependent mortality during the non-breeding period. 


\section{Timing of arrival}

It is well established that the timing of (northern spring) events is becoming earlier in response to warming temperatures (e.g. Parmesan 2007), though changes in the timing of autumn events, such as bird migration, seem to be more variable (e.g. Jenni \& Kéry 2003, Sparks et al. 2007), and how far species can continue to advance their timing is a key issue. Migrants in a broad range of taxonomic groups, including birds (e.g. Hüppop \& Hüppop 2003, Beaumont et al. 2006, Gordo 2007), cephalopods (Sims et al. 2001), fish (Sims et al. 2004), and mammals (Fryxell \& Sinclair 1988), exhibit changing migration phenology in response to both local and regional climate changes. Migration occurs in the context of other life-history activities also affected by climate change, such as breeding (Crick \& Sparks 1999, Dunn 2004, Pike et al. 2006) or hibernation (Humphries et al. 2002), changes in the timing of which will, in turn, also alter migratory schedules (Jenni \& Kéry 2003, Hedenström et al. 2007).

The impact of changing weather phenology can be difficult to predict when different climate components are changing at different rates; for example, white storks Ciconia ciconia may arrive and breed earlier (as a result of warmer temperatures), but this exposes young chicks (which have low thermoregulatory ability) to higher rainfall. Although overall rainfall is predicted to decrease, it is also predicted to be increasingly concentrated, increasing the impact in some years, but decreasing it in others (Jovani \& Tella 2004). The population consequences of such complex interactions between components of the climate system are hard to predict.

In general, reproduction and growth in animals and plants are timed with respect to peak resource availability, so that critical life stages (usually the juveniles) experience optimum conditions. However, the temperature and photoperiod cues used by an organism may not be identical to those used by its food resources, and rates of development may differ, creating the potential for mismatches if changes in cues or responses are either too slow or too fast (Visser \& Both 2005). For example, the response of insect phenology to temperature change $\left(\mathrm{ca} .6 \mathrm{~d} /{ }^{\circ} \mathrm{C}\right.$ ) is greater than that of birds (ca. $2 \mathrm{~d} /{ }^{\circ} \mathrm{C}$ ) (Sparks \& Menzel 2002, Root et al. 2003), creating a mismatch between date of egg-laying and peak food abundance (Both et al. 2004). This has resulted in declines amongst populations of pied flycatcher Ficedula hypoleuca due to low food availability when the chicks hatch (Both et al. 2006). For marine species, annual fluctuations in sea temperatures have been shown to shift the phenology of phyto- and zooplankton blooms by as much as 2 mo between years, resulting in a mismatch between trophic levels
(Edwards \& Richardson 2004). For Atlantic cod Gadus morhua, which in the southern North Sea migrate to specific spawning sites, this has contributed to poorer recruitment since less zooplankton prey is available at the appropriate time for first-feeding cod larvae (Beaugrand et al. 2003), which may also have driven apparent northward distribution shifts in cod and other species (Perry et al. 2005). For other species, however, such as salmon Salmo salar and brown trout $S$. trutta, changes in the timing of migration seem to have had little effect on the breeding schedule (Dahl et al. 2004).

Although the onset of migratory behaviour in birds is determined endogenously (Berthold 2001, Marra et al. 2005), the precise timing of the journey appears flexible and may be modified by conditions en route (Ahola et al. 2004, Schekkerman et al. 2004, Hüppop \& Winkel 2006). Whereas sedentary birds appear to use local weather cues to determine timing of breeding, more dispersive species appear to respond to more extensive climate patterns (Forchhammer et al. 2002, Frederiksen et al. 2004). The effects of climate change will not be uniform across regions, so for long-distance migrants, in particular, the use of local climatic cues that historically have been used to identify the best time to migrate from the non-breeding areas may mean populations no longer arrive at breeding sites at the appropriate time (Visser et al. 2004). This may partly explain why population declines in a wide range of temperate migrant birds are most pronounced for those that migrate the greatest distances (Sanderson et al. 2006).

\section{KNOWLEDGE GAPS}

The numerous threats facing migratory species from climate change highlight the need to consider climate change in developing species conservation programmes (Box 2), but also indicate substantial knowledge gaps. Most of our knowledge about migration patterns and responses relates to birds; we are much more ignorant about impacts in other groups (Table 1). As with any environmental change, inevitably there will be winners and losers. The winners are likely to be those species with greater phenotypic flexibility that use widespread habitats and perhaps display weaker migratory connectivity (individuals from one breeding population may migrate to one of many non-breeding areas and vice versa). Thus, common species are likely to become commoner, and scarce species scarcer, resulting in a general decline in biodiversity (Warren et al. 2001, Julliard et al. 2004).

Loss and deterioration of habitat seem to be the most likely impacts of climate change on vertebrates (Table 1). Migrants may be affected disproportionately because of their reliance on high latitude, high altitude 
Box 2. Quantifying the impacts of climate change on migratory species

Our ability to quantify how and where climate change will affect migratory species depends upon the availability of information from well-designed monitoring programmes and an appropriate statistical framework for modelling these effects. In many cases, monitoring is restricted to a few annual observations in either non-breeding or breeding areas. However, even these programmes can provide information on the effects of climate on migratory species, provided that they are analysed in a way that takes account of all major sources of uncertainty: process variation, observation error, parameter uncertainty and model uncertainty, and the confounding effects of other drivers, e.g. anthropogenic harvesting or land-use change (Harwood \& Stokes 2003).

Fig. B1 shows how such a framework could be developed for monitoring data from Nearctic and Eurasian breeding waders (Charadrii) that winter in the UK. The numbers of each species are monitored throughout the winter (Austin \& Rehfisch 2005), but monitoring on the breeding grounds is logistically much more difficult. Migratory species can be exposed to different weather conditions in the breeding and winter areas, and it may be appropriate to model their response to large-scale climate phenomena, like the North Atlantic Oscillation (NAO), that integrate weather conditions over large areas, rather than to local weather conditions (Forchhammer et al. 2002). In this example, the numbers of wintering waders in the UK at the end of the winter in year $t$ is affected directly by climate conditions $\left(\mathrm{NAO}_{t}\right)$ in that year and indirectly by those in the previous year
$\left(\mathrm{NAO}_{t-1}\right)$, through their effect on the breeding grounds. The relative importance of these effects in different parts of the Northern Hemisphere can be investigated by comparing the responses of Nearctic and Eurasian breeding species, because the temporal and spatial dynamics of the NAO differ regionally (Forchhammer \& Post 2004). It is important that the underlying model takes account of underlying density-dependent processes, so that the numbers of waders $\left(N_{t}\right)$ alive at the end of winter in year $t$ can be affected by their numbers in previous years $\left(N_{t-d i} d \geq 1\right.$, where $d$ is the number of years lag). The overall model would have the following general structure:

$N_{t}=$

$f\left(N_{t-1}, N_{t-d}, \mathrm{NAO}_{t}\right.$, wintering area, $\mathrm{NAO}_{t-1}$, breeding area)

The full model could be either empirical, in which case it can be fitted using autoregressive techniques (Forchhammer et al. 2002), or it could incorporate detailed population dynamic mechanisms using 'hidden process' modelling (Newman et al. 2006), which, by modelling the demographic processes explicitly, allows separation of the different sources of uncertainty. If these hidden processes can be expressed in a linear form, the models can be fitted using classical statistical techniques; more complex, non-linear models will require computer-intensive Bayesian methods (Buckland et al. 2007), although these are becoming increasingly available. Such methods are needed to disentangle the complex climatic and ecological drivers of migratory populations.

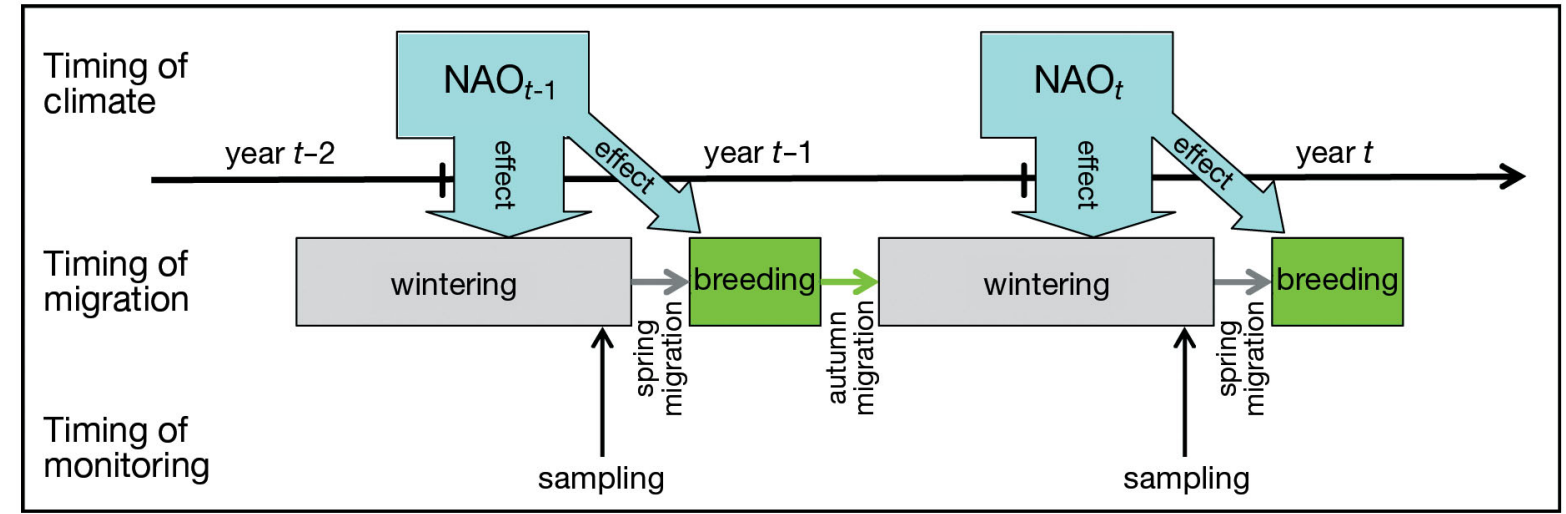

Fig. B1. Framework for monitoring data from Nearctic and Eurasian breeding waders that winter in the UK. NAO: North Atlantic Oscillation; $t$ : time

and wetland habitats as well as on particular stopover sites, which are vulnerable not only to habitat loss (Hassol 2004, MEA 2005), but also to a reduction in seasonality (especially at high latitudes/altitudes) as winter temperatures are increasing faster than summer ones (IPCC 2007). Consequently, we may see either a reduction in migratory tendency-already apparent at mid-latitudes (Fiedler 2003)-or an expansion in the range of resident species. Changes in the timing of migration could also have profound impacts, particularly with regard to mismatch between trophic levels. The impacts of such mismatches at a population level are just beginning to be documented (Beaugrand et al. 2003, Both et al. 2006). If they are, or become, widespread they would represent a major threat, particularly to longer distance migrants.

The 'migratory syndrome' represents a complex array of traits to exploit seasonal environments (Dingle 1996, Piersma et al. 2005, van Noordwijk et al. 2006). The ability of organisms to keep pace with rapid climate change will depend on whether they respond through behavioural plasticity — in which case, the 
degree of adaptation will be limited by the degree to which individuals can modify their behaviour in response to their environment-or through genetic adaptation - in which case, the degree of adaptation is limited by the amount of adaptive genetic variation present (Pulido \& Berthold 2004), which in migrant high Arctic shorebirds, for example, may be low (Meltofte et al. 2007). Migratory species, particularly long-distance migrants, may be more constrained than sedentary species in their ability to adapt to environmental change because of tighter migratory connectivity (Webster et al. 2002) and reduced levels of genetic variation (van Noordwijk et al. 2006); currently, however, evidence to support this latter hypothesis, at least in birds, is limited (Pulido \& Berthold 2003). The rate at which climate is changing is extremely rapid and the ability to evolve in response to environmental change does not necessarily mean the population will track those changes appropriately (Bradshaw \& Holzapfel 2006, Huntley 2007), especially amongst species with long generation times, such as many migratory marine species. Empirical determination of the extent and limits of phenotypic and genotypic adaptation (Pulido \& Berthold 2003), and yardsticks of the environmental change to which they are adapting (Visser et al. 2003) are required.

Climate change impacts occur against a background of intense anthropogenic threats (MEA 2005). Climate change can be identified as having the potential to have a significant effect on population size in $84 \%$ of migratory bird species (Table 2). This is comparable to the number affected by all other anthropogenic threats $(80 \%)$, though the climate change effects may occur further in the future. Reduced water availability as a result of climate change affects the greatest number of species, partly reflecting the importance of wetland habitats for migratory species. These species are already seriously threatened by habitat loss/alteration and increasing agricultural intensification. More generally, $73 \%$ of all bird species identified as being affected by climate change are also under threat from other anthropogenic factors, which may constrain their ability to adapt successfully. Understanding these interactions will be critical in formulating appropriate conservation strategies (Travis 2003).

\section{CONSERVATION OF MIGRANTS: ADAPTATION OR MITIGATION?}

Conservation of migratory species clearly requires an international, co-operative outlook; this is the intention of the CMS (Box 1), which focuses on migratory units, such as bird flyways (Boere \& Stroud 2006). Although the impacts of climate change will be widespread, so far only a few international conventions, notably the CMS (Anonymous 2005) and the Ramsar Convention on Wetlands (van Dam et al. 2002), have considered climate change explicitly; others urgently need to do so. Similarly, few measures specifically tar-

Table 2. Summary of threats faced by 298 migratory bird species listed in the Convention on the Conservation of Migratory Species of Wild Animals (CMS) Appendices. The 'Climate change' column gives the percentage of species affected by each aspect of climate change; subsequent columns indicate the percentage of those species also facing anthropogenic threats or (in the final column) no other anthropogenic threat. The degree of threat faced by the 298 migratory bird species listed on the CMS Appendices was identified by (1) searching Web of Science and Google Scholar using each species name in the title, keywords and abstract and (2) searching the BirdLife International species database (www.birdlife.org/datazone/species) of globally threatened or near-threatened species for mention of specific threats (actual or potential). However, since lack of documentation does not necessarily mean no threats exist, we also used information on species' ecology (distribution, diet, preferred habitat) from del Hoyo et al. (1994-2004), Cramp et al. (1980-1994), and the Global Register of Migratory Species (www.groms.de, Riede 2001) to assign threats. For example, if a species was primarily associated with a specific habitat type widely documented in the literature as being threatened, it was considered threatened by these factors too; similarly, a species associated with a rapidly disappearing habitat, was assumed to be potentially threatened by habitat loss, even if this was not mentioned specifically in the literature. For threats related to climate change, any species with a specialist diet (particularly where there was evidence that prey species were threatened), species with small ranges or those occurring on the poleward edges of continental margins or primarily confined to low-lying coastal areas were also considered threatened

\begin{tabular}{|c|c|c|c|c|c|c|c|}
\hline & $\begin{array}{c}\text { Climate } \\
\text { change }(\%)\end{array}$ & $\begin{array}{l}\text { Habitat } \\
\text { loss (\%) }\end{array}$ & $\begin{array}{c}\text { Agriculture } \\
(\%)\end{array}$ & $\begin{array}{c}\text { Fisheries } \\
(\%)\end{array}$ & $\begin{array}{l}\text { Introduced } \\
\text { species (\%) }\end{array}$ & $\begin{array}{c}\text { Direct mortality } \\
(\%)\end{array}$ & $\begin{array}{c}\text { No human } \\
(\%)\end{array}$ \\
\hline Lower water tables & 42 & 57 & 35 & 35 & 5 & 57 & 27 \\
\hline Higher drought frequency & 30 & 53 & 30 & 30 & 3 & 43 & 19 \\
\hline Altered prey availability & 30 & 35 & 23 & 34 & 20 & 46 & 34 \\
\hline Habitat shifts & 19 & 52 & 29 & 27 & 4 & 48 & 30 \\
\hline Sea level rise & 21 & 48 & 13 & 16 & 6 & 44 & 31 \\
\hline Higher storm frequency & 9 & 27 & 8 & 35 & 35 & 69 & 12 \\
\hline All & 84 & 44 & 23 & 30 & 10 & 56 & 27 \\
\hline
\end{tabular}


geted at adapting to climate change impacts have yet been implemented, but measures undertaken for other reasons may prove beneficial to migrant species attempting to adapt to climate change.

In coastal systems, the economic impacts of climate change are potentially large, especially as a result of sea-level rise and land loss, so protective measures have been taken. The use of hard sea-defences, which impose a fixed limit on the land-sea boundary, will squeeze out coastal habitats as sea levels rise (Fish et al. 2005). In contrast, 'managed re-alignment' of coastal defences, selectively allowing sea-defences to be breached to create a new land-sea interface, has the potential to create habitat. Although plant and invertebrate communities are slow to respond to such habitat creation, near-natural assemblages of more mobile species, such as migratory birds and fish, can be restored in remarkably short periods of time (Atkinson et al. 2004).

In terrestrial ecosystems, human adaptation to changing climatic conditions, by adjusting land use, resource management or exploitation patterns may be sufficient, in principle, to conserve migratory taxa, though different approaches will be required for those species migrating on a broad front and those using a network of discrete sites. Habitat fragmentation impedes the ability of broad-front migrants to adapt their migratory routes and may create new ecological barriers (Travis 2003, Opdam \& Wascher 2004), although this could be reduced by using fragments of natural and semi-natural habitat in a matrix of low intensity land-use to create a permeable landscape surrounding these 'stepping stones'. For other species, maintenance of an ecologically coherent network of stopover sites will be required, and identification of such networks is urgently required to provide a strategic, international overview of site protection priorities. Measures are likely to be necessary throughout the species range, particularly when there is a high degree of population structuring in migratory routes (Martin et al. 2007).

Large shifts in marine communities, across all trophic levels and in a broad range of taxa, have been observed as sea temperatures have increased. It seems unlikely that human-driven adaptation would be feasible in marine ecosystems, even if we knew how to achieve such adaptation. A reduction in anthropogenic climate forcings will thus be required to moderate the effects of climate change in marine systems. However, as on land, other human activities will compromise the ability of marine organisms to adapt to the changing climate (Learmonth et al. 2006); reducing such activities through basin-wide internationally co-ordinated strategies along migration corridors and in particular key areas is likely to prove beneficial (Ferraroli et al. 2004, Southall et al. 2006).
A major challenge in the conservation of migratory species is the shifting of migratory routes. Traditionally, conservation measures have focussed on the management of specific protected areas (Crofts 2004), but animals are responding to climate change by altering their ranges, so sites of conservation importance may be located at the edge, or even beyond, a species' current range. For example, leatherback turtles Dermochelys coriacea are expected to expand their range into higher latitudes as ocean temperatures warm (McMahon \& Hays 2006). Consequently, good foraging areas at the edge of their current range, for example the north-eastern Atlantic (Houghton et al. 2006, Witt et al. 2007), may be increasingly occupied in the future. Thus, it will be important to protect areas that may be used in the future, and to recognise shifts away from currently used sites, as seen for shorebirds wintering in western Europe (Austin \& Rehfisch 2005). Future changes may also remove sites from the network (either because of habitat loss, or because latitudinal shifts in habitat mean that journeys become too long), causing the network to collapse. A novel approach to these problems is exemplified by the creation of 'zakazniks' (reserves which limit hunting and disturbance), which follow the annual migration of saiga antelope Saiga tatarica, rather than being limited to particular sites (Gordon et al. 2004). Seasonally transient protected areas may also be important for conserving commercially exploited migratory marine fish, for example by banning harvesting during the breeding period (Kell et al. 2004).

In addressing the conservation challenges of climate change, the multi-functional Ecosystem Approach, which considers ecosystem preservation within a framework of integrated land-sea spatial planning, outlined by the Convention on Biological Diversity, is likely to be most successful (Crofts 2004). Thus, it is much more likely that conservation goals will be achieved if they are integrated as part of a strategy with wider aims, such as floodplain catchment management, coastal protection, sustainable fisheries management, or preventing deforestation to reduce soil erosion, which have large economic and societal benefits (Sutherland 2004).

\section{FUTURE DIRECTIONS}

Whilst a wide range of global climate effects on wildlife have been posited, projections involve some uncertainty (Araújo et al. 2005), and assessing the potential fates of migrant species will be difficult (Mustin et al. 2007). Traditional approaches, such as climate envelopes and global vegetation models, can be applied to estimate shifts in breeding grounds and 
non-breeding areas, but as migratory species move between different areas, the uncertainties in predictions are multiplied, particularly when biotic interactions are taken into account (Araújo \& Luoto 2007, Martin et al. 2007). A key area of uncertainty is in understanding the mechanisms through which climate change will affect populations, which is an area of active research (e.g. Jonzén et al. 2007), particularly in understanding how climate impacts at one point in the life-cycle affect demographic parameters at later points. Such cross-seasonal impacts will often be modulated by density-dependent effects, and documenting these will be important in order to assess the fate of migrants under changing climates (Ratikainen et al. 2008).

Long-term monitoring programmes (Box 2) have been crucial in identifying conservation priorities and providing base-line data against which the impacts of climate change on ecosystems and migratory species have already been highlighted (Crick \& Sparks 1999, Warren et al. 2001, Hays et al. 2005, Hawkes et al. 2007). An international commitment to long-term support for these schemes is critical for identifying areas where action is required, monitoring the effectiveness of management actions, and because the scientific value of such schemes often grows exponentially with their duration. In addition to supporting those schemes already in existence, developing similar (and compatible) schemes, particularly in tropical and southern hemisphere areas, would greatly improve our understanding of the impacts of climate change on migratory animals.

Although current changes in climate are not unprecedented in geological history, the predicted magnitude of change is outside that experienced at any time during the evolution of most of the world's present fauna, and the rate at which these changes are occurring is extremely rapid (Huntley et al. 2006). Many migratory populations possess the potential to adapt to these changes in the short term, providing their ability to do so is not constrained by other factors, such as over-exploitation or habitat loss and fragmentation (Travis 2003). Perhaps the most important policy goal should be to encourage large, genetically diverse, populations that will enhance the ability of migratory species to adapt to, or exploit, the changes caused by increasing human impacts on the global climate.

Acknowledgements. We thank the invited participants of the Cambridge, 2005 workshop for stimulating discussion: M. Barbieri (CMS), P. Berry (ECI, Oxford), E. Blencowe (Defra), F. Buckel (UKOT Conservation Forum), J. Cortes (Gibraltar ONHS), N. Ellis (SNH), M. Harley (EN), M. Konvicka (Czech Acad. Sci.), E. Lehikoinen (Univ. Turku, Finland), J. Metcalfe (CEFAS), J. O'Sullivan (RSPB), G. Parry (Defra), P. Racey (Univ. Aberdeen), C. Walmsley (CCW), A. Williams (Defra) and I. Woiwod (IACR). We also thank N. Atkins and J. J. D. Greenwood for helpful comments on an earlier version of the manuscript. This paper arose from a project funded by the UK Department for Environment Food and Rural Affairs (Defra, CR0302).

\section{LITERATURE CITED}

Ahola M, Laaksone T, Sippola K, Eeva T, Rainio K, Lehikoenen E (2004) Variation in climate warming along the migration route uncouples arrival and breeding dates. Glob Change Biol 10:1610-1617

Anonymous (2003) Convention on the conservation of migratory species of wild animals. Available at: http://www. cms.int/documents/convtxt/cms_convtxt.htm

Anonymous (2005) Climate change and migratory species (UNEP/CMS/Res 8.13). Convention on the Conservation of Migratory Species of Wild Animals, Nairobi

Araújo MB, Luoto M (2007) The importance of biotic interactions for modelling species distributions under climate change. Glob Ecol Biogeogr 16:743-753

Araújo MB, Pearson RG, Thuiller W, Erhard M (2005) Validation of species-climate impact models under climate change. Glob Change Biol 11:1504-1513

Atkinson PW, Crooks S, Drewitt A, Grant A, Rehfisch MM, Sharpe J, Tyas CJ (2004) Managed realignment in the UK - the first 5 years of colonization by birds. Ibis 146(Suppl):101-110

Austin G, Rehfisch MM (2005) Shifting non-breeding distributions of migratory fauna in relation to climate change. Glob Change Biol 11:31-38

Bairlein F, Hüppop O (2004) Migratory fuelling and global climate change. Adv Ecol Res 35:33-47

Baker AJ, González PM, Piersma T, Niles LJ and others (2004) Rapid population decline in red knots Calidris canutus rufa since 2000: fitness consequences of late arrival and decreased refuelling rates in Delaware Bay. Proc R Soc Lond B Biol Sci 271:875-882

Baker JD, Littnan CL, Johnston DW (2006) Potential effects of sea level rise on the terrestrial habitats of endangered and endemic megafauna in the Northwestern Hawaiian Islands. Endang Species Res 2:21-30

Barber DG, Iacozza J (2004) Historical analysis of sea ice conditions in M'Clintock channel and the Gulf of Boothia, Nunavut: implications for ringed seal and polar bear habitat. Arctic 57:1-4

> Beaugrand G, Brander KM, Lindley JA, Souissi S, Reid PC (2003) Plankton effect on cod recruitment in the North Sea. Nature 426:661-664

> Beaumont LJ, MacAllan IAW, Hughes L (2006) A matter of timing: changes in the first date of arrival and last date of departure of Australian migratory birds. Glob Change Biol 12:1339-1354

> Berger J (2004) The last mile: how to sustain long-distance migration in mammals. Conserv Biol 18:320-331

Berthold P (2001) Bird migration: a general survey. Oxford University Press, Oxford

Boere CG, Stroud DA (2006) The flyway concept: What it is and what it isn't. In: Boere GC, Galbraith CA, Stroud DA (eds) Waterbirds around the world. The Stationery Office, Edinburgh, p 40-47

Boone RB, Hobbs NT (2004) Lines around fragments: effects of fencing on large herbivores. Afr J Range Forage Sci 21:147-158

> Both C, Artemyev AV, Blaauw B, Cowie RJ and others (2004) Large-scale geographical variation confirms that climate 
change causes birds to lay earlier. Proc R Soc Lond B Biol Sci 271:1657-1662

Both C, Bouwhuis S, Lessells CM, Visser ME (2006) Climate change and population declines in a long-distance migratory bird. Nature 441:81-83

Bradshaw WE, Holzapfel CM (2006) Evolutionary response to rapid climate change. Science 312:1477-1478

Buckland ST, Newman KB, Fernández C, Thomas L, Harwood J (2007) Embedding population dynamics models in inference. Stat Sci 22:44-58

Cramp S, Simmons KEL, Perrins CM (1980-1994) Handbook of birds of the Western Palearctic, Vols 1-7. Oxford University Press, Oxford

> Crick HQP, Sparks TH (1999) Climate change related to egglaying trends. Nature 399:423-424

$>$ Crofts R (2004) Linking protected areas to the wider world: a review of approaches. J Environ Policy Plann 6:143-156

> Croxall JP, Trathan PN, Murphy EJ (2002) Environmental change and Antarctic seabird populations. Science 297: $1510-1514$

Dahl J, Dannewitz J, Karlsson L, Petersson E, Löf A, Ragnarsson B (2004) The timing of spawning migration: implications of environmental variation, life history, and sex. Can J Zool 82:1864-1870

del Hoyo J, Elliott A, Sargatal J (1994-2004) Handbook of the birds of the world, Vols 1-9. Lynx Edicions, Barcelona

Derocher AE, Lunn NJ, Stirling I (2004) Polar bears in a warming climate. Integr Comp Biol 44:163-176

$>$ Deveson ED, Drake VA, Hunter DM (2005) Evidence from traditional and new technologies for northward migrations of Australian plague locusts (Chortoicetes terminifera) (Walker) (Orthoptera:Acrididae) to western Queensland. Austral Ecol 30:920-943

Dingle H (1996) Migration: the biology of life on the move. Oxford University Press, Oxford

Dunn P (2004) Breeding dates and reproductive performance. Adv Ecol Res 35:69-87

Edwards M, Richardson AJ (2004) Impact of climate change on marine pelagic phenology and trophic mismatch. Nature 430:881-884

Ferraroli S, Georges JY, Gaspar P, le Maho Y (2004) Endangered species: where leatherback turtles meet fisheries. Nature 429:521-522

Fiedler W (2003) Recent changes in migratory behaviour of birds: a compilation of field observations and ringing data. In: Berthold P, Gwinner E, Sonnenschein E (eds) Avian migration. Springer, Berlin, p 21-38

> Fish MR, Côté IM, Gill JA, Jones AP, Renshoff S, Watkinson AR (2005) Predicting the impact of sea-level rise on Caribbean sea turtle nesting habitat. Conserv Biol 19: $482-491$

Forcada J, Trathan PN, Reid K, Murphy EJ (2005) The effects of global climate variability in pup production of Antarctic fur seals. Ecology 86:2408-2417

Forchhammer MC, Post E (2004) Using large-scale climate indices in climate change ecology studies. Popul Ecol $46: 1-12$

Forchhammer MC, Post E, Stenseth NC (2002) North Atlantic Oscillation timing of long- and short-distance migration. J Anim Ecol 71:1002-1014

Frederiksen M, Harris MP, Daunt F, Rothery P, Wanless S (2004) Scale-dependent climate signals drive breeding phenology of three seabird species. Glob Change Biol 10:1214-1221

Fryxell JM, Sinclair ARE (1988) Causes and consequences of migration by large herbivores. Trends Ecol Evol 3: $237-241$
Gauthier-Clerc M, Lebarbenchon C, Thomas F (2007) Recent expansion of highly pathogenic avian influenza H5N1: a critical review. Ibis 149:202-214

Gill JA, Norris K, Potts PM, Gunnarsson TG, Atkinson PW, Sutherland WJ (2001) The buffer effect and large scale population regulation in migratory birds. Nature 412: 436-438

Godley BJ, Broderick AC, Glen F, Hays GC (2002) Temperature dependent sex determination of Ascension Island green turtles. Mar Ecol Prog Ser 226:115-124

Gordo O (2007) Why are bird migration dates shifting? A review of weather and climate effects on avian migratory phenology. Clim Res 35:37-38

Gordon IJ, Hester AJ, Festa-Bianchet M (2004) The management of wild large herbivores to meet economic, conservation and environmental objectives. J Appl Ecol 41: 1021-1031

Green AJ, Figuerola J (2005) Recent advances in the study of long-distance dispersal of aquatic invertebrates via birds. Divers Distrib 11:149-156

Gunnarsson TG, Gill JA, Newton J, Potts PM, Sutherland WJ (2005) Seasonal matching of habitat quality and fitness in migratory birds. Proc R Soc Lond B Biol Sci 272:2319-2323

Harwood J (2001) Marine mammals and their environment in the twenty-first century. J Mammal 82:630-640

Harwood J, Stokes K (2003) Coping with uncertainty in ecological advice: lessons from fisheries. Trends Ecol Evol 18:617-622

Hassol SJ (2004) Impacts of a warming Arctic: the Arctic Climate Impact Assessment. Cambridge University Press, Cambridge

> Hawkes LA, Broderick AC, Godfrey MH, Godley BJ (2007) Investigating the potential impacts of climate change on a marine turtle population. Glob Change Biol 13:923-932

Hays GC (2008) Sea turtles: a review of some key recent discoveries and remaining questions. J Exp Mar Biol Ecol 356:1-7

Hays GC, Richardson AJ, Robinson C (2005) Climate change and marine plankton. Trends Ecol Evol 20:337-344

Hedenström A, Barta Z, Helm B, Houston AI, McNamara JM, Jonzén N (2007) Migration speed and scheduling of annual events by migrating birds in relation to climate change. Clim Res 35:79-91

Houghton JDR, Doyle TK, Wilson MW, Davenport J, Hays GC (2006) Jellyfish aggregations and leatherback turtle foraging patterns in a temperate coastal environment. Ecology 87:1967-1972

Humphries MM, Thomas DW, Speakman JR (2002) Climatemediated energetic constraints on the distribution of hibernating mammals. Nature 418:313-316

Hunter E, Metcalfe JD, Arnold GP, Reynolds JD (2004) Impacts of migratory behaviour on population structure in North Sea plaice. J Anim Ecol 73:377-385

> Huntley B (2007) Evolutionary response to climatic change? Heredity 98:247-248

Huntley B, Collingham YC, Green RE, Hilton GM, Rahbek C, Willis SG (2006) Potential impacts of climatic change upon geographical distributions of birds. Ibis 148:8-28

> Hüppop O, Hüppop K (2003) North Atlantic Oscillation and timing of spring migration in birds. Proc R Soc Lond B Biol Sci 270:233-240

Hüppop O, Winkel W (2006) Climate change and timing of spring migration in the long-distance migrant Ficedula hypoleuca in central Europe: the role of spatially different temperature changes along migration routes. J Ornithol 147:344-353

IPCC (Intergovernmental Panel on Climate Change) (2007) 
IPCC Fourth Assessment Report. Climate change 2007: synthesis report. Available at: www.ipcc.ch/ipccreports/ ar4-syr.htm

Jenni L, Kéry M (2003) Timing of autumn bird migration under climate change: advances in long-distance migrants, delays in short-distance migrants. Proc R Soc Lond B Biol Sci 270:1467-1471

Jensen RA, Madsen J, O'Connell M, Wisz MS, Mehlum F (2008) Prediction of the distribution of Arctic-nesting pinkfooted geese under a warmer climate scenario. Glob Change Biol 14:1-10

> Jonzén N, Ergon T, Lindén A, Stenseth NC (2007) Introduction (Bird migration and climate, Spec Issue 17). Clim Res 35:1-3

> Jovani R, Tella JL (2004) Age-related environmental sensitivity and weather mediated nestling mortality in white storks Ciconia ciconia. Ecography 27:611-618

Julliard R, Jiguet F, Couvet D (2004) Evidence for the impact of global warming on the long-term population dynamics of common birds. Proc R Soc Lond B Biol Sci 271(Suppl):490-492

Keiper CA, Ainley DG, Allen SG, Harvey JT (2005) Marine mammal occurrence and ocean climate off central California, 1986 to 1994 and 1997 to 1999. Mar Ecol Prog Ser 289:285-306

Kell LT, Scott R, Hunter E (2004) Implications for current management advice for North Sea plaice: Part 1. Migration between the North Sea and English Channel. J Sea Res 51:287-299

King DA (2004) Climate change science: adapt, mitigate or ignore? Science 303:176-177

Kokko H (1999) Competition for early arrival in migratory birds. J Anim Ecol 68:940-950

Learmonth JA, Macleod CD, Santos MB, Pierce GJ, Crick HQP, Robinson RA (2006) Potential effects of climate change on marine mammals. Oceanogr Mar Biol 44: 429-456

Liechti F (2006) Birds: blowin' by the wind? J Ornithol $147: 202-211$

Lotze HK, Lenihan HS, Bourque BJ, Bradbury RH and others (2006) Depletion, degradation and recovery potential of estuaries and coastal seas. Science 312:1806-1809

- Marra PP, Francis CM, Mulvihill RS, Moore FR (2005) The influence of climate on the timing and rate of spring bird migration. Oecologia 142:307-315

Martin TG, Chadès I, Arcese P, Marra PP, Possingham HP, Norris DR (2007) Optimal conservation of migratory species. PLoS One 2:e751. doi:10.13171/journal.pone0000751

McMahon CR, Hays GC (2006) Thermal niche, large scale movements and implications of climate change for a critically endangered marine vertebrate. Glob Change Biol 12:1330-1338

MEA (Millennium Ecosystem Assessment) (2005) Ecosystems and human well-being: biodiversity synthesis. World Resources Institute, Washington, DC

Meehl GA, Washington WM, Collins WD, Arblaster JM and others (2005) How much more global warming and sealevel rise? Science 307:1769-1772

Meltofte H, Piersma T, Boyd H, McCaffery B and others (2007) Effects of climate change on the breeding ecology of Arctic shore birds. Meddelelser om Grønland: Bioscience 59. Danish Polar Centre, Copenhagen

Moore SE, Grebmeier JM, Davies JR (2003) Gray whale distribution relative to forage habitat in the northern Bering Sea: current conditions and retrospective summary. Can J Zool 81:734-742

Mustin K, Sutherland WJ, Gill JA (2007) The complexity of predicting climate-induced ecological impacts. Clim Res 35:165-175
Newman KB, Buckland ST, Lindley ST, Thomas L, Fernández C (2006) Hidden process models for animal population dynamics. Ecol Appl 16:74-86

Newton I (2006) Can conditions experienced during migration limit the population levels of birds? J Ornithol 147:146-166

- Newton I (2007) Weather-related mass-mortality events in migrants. Ibis 149:453-467

> Norris DR, Marra PP, Kyser TK, Sherry TW, Ratcliffe LM (2004) Tropical winter habitat limits reproductive success on the temperate breeding grounds in a migratory bird. Proc R Soc Lond B Biol Sci 271:59-64

Oedekoven CS, Ainley DG, Spear LB (2001) Variable responses of seabirds to change in marine climate: California Current, 1985-1994. Mar Ecol Prog Ser 212:265-281

> Olsen B, Munster VJ, Wallensten A, Waldeström J, Osterhaus ADME, Foucheir RAM (2006) Global patterns of Influenza A virus in wild birds. Science 312:384-388

Opdam P, Wascher D (2004) Climate change meets habitat fragmentation: linking landscape and biogeographical scale levels in research and conservation. Biol Conserv 117:285-297

> Osborn TJ, Briffa KR (2006) The spatial extent of 20th-century warmth in the context of the last 1200 years. Science 311:841-844

Paradis E, Baillie SR, Sutherland WJ, Gregory RD (1998) Patterns of natal and breeding dispersal in birds. J Anim Ecol 67:518-536

Parmesan C (2007) Influences of species, latitudes and methodologies on estimates of phenological response to global warming. Glob Change Biol 13:1860-1872

> Parmesan C, Yohe G (2003) A globally coherent fingerprint of climate change impacts across natural systems. Nature 421:37-42

Perry AL, Low PJ, Ellis JR, Reynolds JD (2005) Climate change and distribution shifts in marine species. Science 308:1912-1913

Piersma T, Lindström $\AA$ (2004) Migrating shorebirds as integrative sentinels of global environmental change. Ibis 146:61-69

Piersma T, Pérez-Tris J, Mouritsen H, Bauchinger U, Bairlein F (2005) Is there a 'migratory syndrome' common to all migrant birds? Ann NY Acad Sci 1046:282-294

Pike DA, Antworth RL, Stiner JC (2006) Earlier nesting contributes to shorter nesting seasons for the loggerhead seaturtle, Caretta caretta. J Herpetol 40:91-94

Pörtner HO, Langenburgh M, Reipschläger A (2004) Biological impact of elevated ocean $\mathrm{CO}_{2}$ concentrations: lessons from animal physiology and earth history. J Oceanogr 60:705-718

Pounds JA, Bustamante MR, Coloma LA, Consuegra JA and others (2006) Widespread amphibian extinctions from epidemic disease driven by global warming. Nature 439: 161-167

Pulido F, Berthold P (2003) Quantitative genetic analysis of avian migration. In: Berthold P, Gwinner E, Sonnenschein E (eds) Avian migration. Springer, Berlin, p 53-77

Pulido F, Berthold P (2004) Microevolutionary response to climate change. Adv Ecol Res 35:151-176

Ratikainen II, Gill JA, Gunnarsson TG, Sutherland WJ, Kokko $\mathrm{H}$ (2008) When density dependence is not instantaneous: theoretical developments and management implications. Ecol Lett 11:184-198

> Rehfisch MM, Austin GE, Freeman SN, Armitage MJS, Burton NHK (2004) The possible impact of climate change on the future distributions and numbers of waders on Britain's non-estuarine coast. Ibis 146(Suppl):70-80 
Riede K (2001) The Global Register of Migratory Species from global to regional scales. Bundesamt für Naturschutz, Bonn

Root TL, Price JT, Schneider SH, Rosenzweig C, Pounds JA (2003) Fingerprints of global warming on plants and animals. Nature 421:57-60

Sala OE, Chapin FS, Armesto JJ, Berlow E and others (2000) Global biodiversity scenarios for the year 2100. Science 287:1770-1774

Sanderson FJ, Donald PF, Pain DJ, Burfield IJ, van Bommel FPJ (2006) Long-term population declines in Afro-Palearctic migrant birds. Biol Conserv 131:93-105

Schekkerman H, Tulp I, Calf KM, de Leeuw JJ (2004) Studies on breeding shorebirds in Medusa Bay, Taimyr, in 2002. Alterra, Wageningen

Sillett TS, Holmes RT (2002) Variation in survivorship of a migratory songbird throughout its annual cycle. J Anim Ecol 71:296-308

Sims DW, Genner MJ, Southward AJ, Hawkins SJ (2001) Timing of squid migration reflects North Atlantic climate variability. Proc R Soc Lond B Biol Sci 268:2607-2611

Sims DW, Wearmouth VJ, Genner MJ, Southward AJ, Hawkins SJ (2004) Low-temperature-driven early spawning migration in a temperate marine fish. J Anim Ecol 73:333-341

Sims DW, Witt MJ, Richardson AJ, Southall EJ, Metcalfe JD (2006) Encounter success of free-ranging marine predator movements across a dynamic prey landscape. Proc R Soc Lond B Biol Sci 273:1195-1201

Southall EJ, Sims DW, Witt MJ, Metcalfe JD (2006) Seasonal space-use estimates of basking sharks in relation to protection and political-economic zones in the NE Atlantic. Biol Conserv 132:33-39

Sparks TH, Menzel A (2002) Observed changes in seasons: an overview. Int J Climatol 22:1715-1725

Sparks TH, Huber K, Bland RL, Crick HQP and others (2007) How consistent are trends in arrival (and departure) dates of migrant birds in the UK? J Ornithol 148:503-511

Sutherland WJ (1996) From individual behaviour to population ecology. Oxford University Press, Oxford

Sutherland WJ (1998) Evidence for flexibility and constraint in migration systems. J Avian Biol 29:441-446

Sutherland WJ (2004) A blueprint for the countryside. Ibis 146(Suppl):230-238

Thirgood S, Mosser A, Tham S, Hopcraft G and others (2004) Can parks protect migratory ungulates? The case of the Serengeti wildebeest. Anim Conserv 7:113-120

Thomas CD, Cameron A, Green RE, Bakkenes M and others

Editorial responsibility: Jeffrey Seminoff,

La Jolla, California, USA
(2004) Extinction risk from climate change. Nature 427:145-148

Travis JMJ (2003) Climate change and habitat destruction: a deadly anthropogenic cocktail. Proc R Soc Lond B Biol Sci 270:467-473

van Dam R, Gitay H, Finlayson M (2002) Climate change and wetlands: impacts, adaptation and mitigation (Ramsar/ CoP8/Doc 11). Ramsar, Valencia

$>$ van Noordwijk AJ, Pulodo F, Helm B, Coppack T and others (2006) A framework for the study of genetic variation in migratory behaviour. J Ornithol 147:221-233

> Visser ME, Both C (2005) Shifts in phenology due to global climate change: the need for a yardstick. Proc R Soc Lond B Biol Sci 272:2561-2569

Visser ME, Adriaensen F, van Balen JH, Blondel J and others (2003) Variable responses to large-scale climate change in European Parus populations. Proc R Soc Lond B Biol Sci 270:367-372

Visser ME, Both C, Lambrechts MM (2004) Global climate change leads to mistimed avian reproduction. Adv Ecol Res 35:89-110

Walther GR, Post E, Convey P, Menzel A and others (2002) Ecological responses to recent climate change. Nature 416:389-395

> Waluda C, Rodhouse P, Podestá G, Trathan P, Pierce G (2001) Surface oceanography of the inferred hatching grounds of Illex argentinus (Cephalopoda: Ommastrephidae) and influences on recruitment variability. Mar Biol 139: 671-679

> Warren MS, Hill JK, Thomas JA, Asher J and others (2001) Rapid responses of British butterflies to opposing forces of climate and habitat change. Nature 414:65-69

> Webster MS, Marra PP, Haig SM, Bensch S, Holmes RT (2002) Links between worlds: unravelling migratory connectivity. Trends Ecol Evol 17:76-83

Weimerskirch H, Inchausti P, Guinet C, Barbraud C (2003) Trends in bird and seal populations as indicators of a system shift in the southern ocean. Antarct Sci 15:249-256

Winstanley D, Spencer R, Williamson K (1974) Where have all the whitethroats gone? Bird Study 21:1-14

Wirth T, Bernatchez L (2003) Decline of North Atlantic eels: a fatal synergy. Proc R Soc Lond B Biol Sci 270:681-688

Witt MJ, Broderick MC, Johns DJ, Martin C, Penrose R, Hoogmoed MS, Godley BJ (2007) Prey landscapes help identify potential foraging habitats for leatherback turtles in the NE Atlantic. Mar Ecol Prog Ser 337:231-243

Zöckler C, Lysenko I (2000) Water birds on the edge: first circumpolar assessment of climate change impact on Arctic breeding wader birds. WCMC Biodivers Ser 11:20-25

Submitted: December 7, 2007; Accepted: March 28, 2008

Proofs received from author(s): May 29, 2008 